\title{
Peter Carey's Laptop
}

\author{
ROWAN WILKEN
}

SWINBURNE UNIVERSITY

Some computers will become museum pieces. The fetishizing drive has no limits, by definition; it will never let go.

Jacques Derrida, Paper Machine ${ }^{1}$

\section{- INTRODUCTION}

'Where should we start? Well, by the working instrument ...' For Barthes, who wrote these words, the instrument in question was the typewriter belonging to the French writer Philippe Sollers. In this article, it is the two laptop computers belonging to the New York-based expatriate Australian writer Peter Carey. The first is a matt black Apple Mac Classic, with a missing 'o' key on its keyboard, running OS7.6 with Eudora email software installed. ${ }^{3}$ The second is a white G4 Mac iBook.

In 2001, the State Library of Victoria in Melbourne, Australia, built on its holdings of Australian literary manuscripts by acquiring all the papers and drafts and other items associated with Carey's Booker Prize winning novel, True History of the Kelly Gang, published in 2000. The centrepiece of this acquisition was Carey's laptop computer. The ostensible reason given for the laptop's inclusion within the collection of Carey material was that it represented the simplest means of capturing 
all email correspondence relating to True History between Carey and his American editor at Knopf, Gary Fisketjon. ${ }^{4}$ In early 2008, the library added to its Carey collection by purchasing further typescripts, notebooks and other materials. Again, the crucial item in the acquisition was Carey's laptop, in this case the white G4 Mac iBook, which contained all drafts for his books Wrong about Japan and My Life as a Fake, multiple drafts for the novel Theft: A Love Story, modified drafts of the 2002 work Four Easy Pieces, drafts for the libretto Bliss and the complete draft for His Illegal Self.

The above explanation of, and justification for, their acquisition, however, tells only a small part of the story of the full significance of these laptops, especially the first of the two. The acquisition of Carey's black Mac Classic laptop coincided with a number of significant, larger scale events: the AUD\$200 million redevelopment of the library's buildings, including the refurbishment of its domed reading room and the creation of major gallery spaces; preparations for the launch of a major Ned Kelly retrospective; and an ongoing industrial dispute involving library staff, the Community and Public Sector Union, and the Victorian government. It is in this broader context that I want to situate the acquisition of Carey's first laptop computer. Drawing on the critical literature on machines and textual production, as well as press reportage of the above events and my own personal experiences as a past employee at the State Library of Victoria, I will argue that Carey's first laptop constitutes a key technological artefact that can be seen to operate, especially at the time of its acquisition, as an important talisman that combines three distinctive yet interconnected understandings of code and labour. First, it can be understood not only as a key object within the library's overall collection of artefacts relating to Carey and the production of his novel The True History of the Kelly Gang. More specifically, part of its value lies in the antiquated code of the word processing software which is seen to permit privileged access to the 'true history' of Carey's own creative drive or creative unconscious. His laptop, in this sense, provides the 'code', if you like, that unlocks the inner workings of Carey's creative labours. Second, through its public display alongside other textual objects (mostly books), the laptop underwent semiotic 'recoding' within official library reports and press coverage. Here it was recast as a technological object of and for the future, and was deployed in ways that bolstered a reconstructed corporate image that endeavoured 
to reposition the library as a vital, contemporary cultural site and key player in Melbourne's institutional gallery scene. Third, Carey's laptop was also 'recodified' as an object for the future in another, different, sense: one that lent support to internal library initiatives to restructure its own labour force. In this context the laptop formed a crucial symbolic acquisition which spoke to certain desires within the State Library of Victoria's management at that time, and which responded to similar moves at major libraries elsewhere around the world, to embrace collection digitisation as the path forward, especially as a way to reduce labour and other running costs.

\section{—FROM HARD DRIVE TO CREATIVE DRIVE: AURA IN THE AGE OF DIGITAL TEXT PRODUCTION}

In an interview first published in La Quinzaine Littéraire in 1996, Jacques Derrida remarks that to write with computers 'is to participate in a partly new plot'. ${ }^{6}$ For critics such as Nietzsche and Ong, the impact of machines on writing and writers is dramatic. According to Nietzsche, 'our writing tools are also working on our thoughts', while for Ong, 'technologies are not mere exterior aids but also interior transformations of consciousness. ${ }^{7}$ When Derrida was asked how precisely his writing has changed since he had been writing on his computer ('this little Mac', as he refers to it), he was rather more circumspect:

I'm incapable of replying. I don't know what criteria to measure it by. There's certainly a change but I'm not sure that it affects what is written, even if it does modify the way of writing ... When I sit down at the table and switch on my computer, the scenario is different but I don't know if that translates into a change in what is written. ${ }^{8}$

Despite his cautious response, elsewhere in the interview Derrida pinpoints one of the key ways by which computers alter the act of writing and what is written: the ability to repeatedly edit text in word processing software.

It is a different kind of timing, a different rhythm. First of all you correct faster and in a more or less indefinite way. Previously, after a certain number of versions (corrections, erasures, cutting and pasting, Tippex), everything came to a halt-that was enough. Not that you thought the text was perfect, but, after a certain period of metamorphosis, the process was interrupted. With the computer [and word processing software], 
everything is rapid and so easy; you get to thinking that you can go on revising forever. ${ }^{9}$

Mark Poster develops a very similar line of argument to this, albeit one that places greater emphasis on the consequences of computer-facilitated editing for the materiality of text:

Compared to the pen, the typewriter or the printing press, the computer dematerializes the written trace ... Since these letters are no more than representations of ASCII codes contained in Random Access Memory, they are alterable practically at the speed of light. The writer encounters his or her words in a form that is evanescent, instantly transformable, in short, immaterial. By comparison, the inertial trace of ink scratched by hand or pounded by typewriter keys on to a page is difficult to change or erase. ${ }^{10}$

Poster's larger point is that our use of the computer suggests (to borrow Kittler's words) that 'three moments of writing coincide: the equipment, the thing, and the agent'; as a result of this coincidence, Poster argues, 'the screen-object and the writing-subject merge into an unsettling simulation of unity'. ${ }^{11}$ According to Derrida and Poster, one effect of this union and the ability to edit text seemingly endlessly is that it appears to bring computer writing closer to speech. As Derrida puts it, the computer 'seems to restore a quasi immediacy of the text, a desubstantialized substance, more fluid, lighter, and so closer to speech, and even to so-called interior speech'. ${ }^{12}$ And, for Poster, 'the writer ... confronts a representation that is similar in its spatial fragility and temporal simultaneity to the contents of the mind or the spoken word,. ${ }^{13}$ These are significant insights, not only in that they suggest one explanation for the library's purchase of the laptop was that it permitted access to Carey's authorial voice, but also in light of the fact that Carey's novel, True History of the Kelly Gang, received wide praise for its imaginative recreation of the bushranger's own voice'. ${ }^{14}$ Dedicated to the infant child Kelly is yet to see, True History is 'couched as a rough-hewn apologia drawn from 13 parcels of dogeared papers Kelly has written while on the run' and crafted by Carey in 'the unmistakeable grammar and syntax we recognise from the bushranger's famous Jerilderie Letter'. ${ }^{15}$ As Carey states in a 2001 interview: 'The one voice that was in my ear was Ned Kelly's voice in [his] Jerilderie Letter. And it really seemed to me that this was the character's DNA. ${ }^{, 16}$ Numerous reviews draw explicit attention to 
this feature of the book. One such review, in Time, suggests that 'the power and charm of True History arise not from fidelity to facts but rather from the voice Carey invents for Ned Kelly'. ${ }^{17}$ In The Times Literary Supplement, this conceit is described as 'brilliantly executed', while in Newsweek it is suggested that Carey's recreation of Ned Kelly's voice is 'so adroit that you never doubt it's Kelly's own words you're reading'. ${ }^{18}$ As Carey has noted in subsequent interviews, his established practice of working up a text through multiple drafts aided him in capturing in writing 'the Kelly voice.' ${ }^{19}$

A further impact of computers on writing, one which has a direct bearing on our understanding of Carey's laptop and the significance of its acquisition, concerns Poster's subsequent argument that 'the interrelation of computerized word processing and authorship changes other aspects of the subject'. ${ }^{20}$ The ability to endlessly edit text leads Poster to suggest that 'the computer monitor depersonalizes the text, removes all traces of individuality from writing, deindividualizes the graphic mark, ${ }^{21}$ Echoing the sentiments of Walter Benjamin on the effects of mechanical reproduction, Poster, writing in 1990, concludes that the editing capacities of word processing software have an overall detrimental impact for writing insofar as they serve to erode the aura of the original object. ${ }^{22}$ 'Large sums are paid by collectors and libraries for such marks of authenticity', he writes. 'One cannot imagine similar interest paid to a file on a floppy disk where traces of originality, authenticity, individuality are precluded. ${ }^{23}$

Six years later, in his 1996 interview, Derrida draws a very different conclusion. What he recognises, and Poster fails to take into account, is our long-standing fascination with writers and their instruments. We have been and continue to be captivated by 'the outward trappings of creation in contemporary writers', especially writers' use of older technologies, such as pens and typewriters ${ }^{24}$ indeed, in 2007 the State Library of Victoria acquired the typewriter belonging to Henry Handel Richardson (the pen-name of Ethel Florence Lindsay Richardson), author of the Getting of Wisdom. ${ }^{25}$ This fascination has continued with writers' use of newer technologies, such as portable computers, as with the library purchasing Carey's laptop for an undisclosed but substantial sum, and desktop computers, with the library acquiring the hard drive (not the whole computer) belonging to the award-winning Australian writer Alex Miller. ${ }^{26}$ In short, our search for the 'marks of 
authenticity' (to borrow Poster's phrase) is ongoing and has merely followed the move from analogue to digital. Thus, in contrast to Poster who cannot envisage a scenario where one would show interest in a digital file, it comes as no surprise to Derrida that not only will the computer become a fetishised object ('Even the computer belonging to the "great writer" or "great thinker" will be fetishized, like Nietzsche's typewriter'). ${ }^{27}$ In addition to computers, written drafts produced on them will also become highly prized: 'Some particular draft that was prepared or printed on some particular software, or some particular disk that stores a stage of a work in progress-these are the kinds of things that will be fetishized in the future. ${ }^{, 28}$ Indeed, as one journalist reporting the initial acquisition of Carey's laptop put it, 'because most authors don't handwrite or type out their manuscripts on typewriters any more, computers and their contents have become the nearest thing to original work and authenticated stages of development. ${ }^{29}$

And yet, the fragility of the original Carey laptop and the mutability of the digital files contained on it only serve to heighten the aura of Carey's work by increasing our distance from these 'authenticated stages' of creative development. Unlike Kelly's original Jerilderie Letter, which is also held by the State Library of Victoria and is available for research viewing, at present:

what you cannot see, contemplate or critique is Carey's manuscript-his revisions, different drafts, the substitution of one word for another, perhaps an entire passage angrily crossed out. All that compositional magic lies mouldering inside the machine, too delicate to access in case it is changed or lost. ${ }^{30}$

As the library's former manuscripts librarian, Jock Murphy, states, 'acquisition of the [first Carey] laptop presents new preservation challenges, in particular the need to transfer the information to a format that will survive after the laptop eventually becomes defunct'. ${ }^{31}$

The original hardware (a mac classic) is in a stable condition. However, the software (OS 7.6) is no longer supported by apple, and many programs (such as Eudora email) are no longer readily available. In terms of access to the files as they were created, it was decided that the best way to achieve this would be to re-create the original computer in every way. A 'Clone' in this context is a full replica of the original machine. To this end, 
and as a 'one off', the library has acquired a replica, and is currently in the process of creating a clone, with the old software (known as mac 'classic') environment installed. ${ }^{32}$

Part of the paradox of reproduction, Hillel Schwartz reminds us, is that 'it is within an exuberant world of copies that we arrive at our experience of originality'. ${ }^{33}$ The 'culture of the copy', he writes, 'bristles with paradox', and is 'at once degenerate and regenerate: $:^{34}$ degenerate in that copies arguably distance us from originals and originality (thereby withering aura); regenerate in the sense that, paradoxically, in other ways they appear to return us to, and mingle with, the original and the authentic and what Derrida would describe as our ongoing obsession with moments of inauguration. So it is in the case of Carey's laptop: in the present age, we are led to believe, multiple electronic drafts and cloned copies of them are what bring us closer to originality and authenticity. This is the first sense in which, I argue, Carey's laptop acts as an important talisman for the library: it holds the promise of 'effectively tell[ing] the inside story of the creation of True History of the Kelly Gang' - this is a perspective that is carried through to the laptop's public display. ${ }^{35}$

\section{—OBJETS D'ART AND THE POLITICS OF DISPLAY}

'Computers', Steven Lubar writes, 'have been prime objects for exhibition ever since their invention. ${ }^{36}$ The public display of Peter Carey's laptop continues this tradition. Four years after its purchase, Carey's matt black Macintosh computer, with its missing 'o' key, was included in the Mirror of the World permanent exhibition, which is staged in one of two narrow upper galleries that hug and encircle the outer walls of the library's octagonal, domed La Trobe Reading Room. The Mirror of the World exhibition, which opened in late 2005 , is intended as a celebration of books, and 'provides an overview of the history of book production, design and illustration, with a display of fine examples from the Library's collections dating from the Middle Ages to the present day'. ${ }^{37}$

The laptop is located almost at the midway point of the exhibition, and is to be found enclosed within a glass display case, taking pride of place between various papers and other items relating to Carey's work and especially True History of the Kelly Gang. ${ }^{38}$ The inclusion of the laptop in the exhibit is to 'provide an opportunity to reveal to the public the way in which an author's initial idea is slowly transformed 
into a final text'. ${ }^{39}$ Close by, to the left of the Carey display, is another cabinet, this one dedicated to the work of the American beat writer, Jack Kerouac. It features a number of his books, including the novel On the Road.

The inclusion of the laptop in the exhibition is significant. By placing it on display-with all the accompanying signifiers of artistic and museological importance, such as the glass case, subdued lighting, nearby thermohygrograph, and so on-Carey's computer is elevated from an everyday functional tool, or 'mere object', into an 'Art Object' ${ }^{40}$ a process of transformation which the philosopher and art critic Arthur Danto famously referred to as the transfiguration of the commonplace'. ${ }^{41}$

That it is to be found within a library-as opposed to, say, a museum of science and technology ${ }^{42}$-is also important, and makes its appearance all the more striking. Here we have a computer sitting in a prominent clearing amid a forest of books. The contrast is marked. As a historical artefact, this object might have appeared less out of place had it been displayed alongside, for argument's sake, Henry Handel Richardson's typewriter, Alex Miller's hard drive or (were it possible to obtain such items on loan) Kerouac's typewriter and famous scroll manuscript of On the Road. The computer would have made perfect sense, in short, as part of a display of writers and the tools of their trade. That it is not displayed in this way is significant. By placing it alongside books and other printed materials in an exhibition dedicated to the history of the book, the laptop can be read-and, I would suggest, is encouraged to be read-as signalling the future of the book. The juxtaposition that is created through the prominent display of Carey's laptop amid books draws explicit attention to the growing importance of digital technologies in mediating and actively shaping all facets of creative production, from research, to drafts, to finished product.

This last point is especially important when we consider the wider context of the laptop's purchase and display. Exhibitions, Sharon Macdonald notes, 'rarely seek to explain their contents in terms of a broader social and political context'. ${ }^{43}$ Attending to such contexts is important, she argues, as displays 'always involve the culturally, socially and politically saturated business of negotiation and valuejudgement; and they always have cultural, social and political implications', which of course extend beyond the exhibition itself. ${ }^{44}$ In the case of the Carey acquisitions, 
these purchases dovetail with a series of larger strategic steps taken by the State Library of Victoria that sought to reposition it as progressive and, in the words of one journalist, 'scrubbed up for the 21 st century'. ${ }^{45}$

The biggest of these was the AUD $\$ 200$ million redevelopment of the library buildings - part of an AUD $\$ 1$ billion major projects initiative to revitalise Victoria's cultural institutions, which was introduced by the Kennett Coalition government and continued by the Bracks Labor government. ${ }^{46}$ The library redevelopment increased its total floor space threefold, so that, upon completion, it occupied seventeen distinct buildings on six levels across nearly two hectares of land. ${ }^{47}$ While much press attention was given to the restoration and refurbishment of the 1913 domed reading room, renamed the La Trobe Reading Room, a key initiative within the redevelopment was the creation of a number of major exhibition spaces. ${ }^{48}$ As noted above, two of these were located on the upper fourth and fifth levels of the dome-one dedicated to the history of the book (which features Carey's laptop), the other to the history of Melbourne and Victoria. ${ }^{49}$

Two further gallery spaces were also created elsewhere in the library: the Cowan Gallery (to exhibit the library's substantial documentary art collection) and the Keith Murdoch Gallery (to house travelling and in-house exhibitions). One of the most successful of the early shows to be staged in the Keith Murdoch Gallery, and one which drew from the recently acquired Carey collection of papers (although not the laptop), was the Kelly Culture exhibition. Running between February and May 2003, the exhibition explored the role of Ned Kelly in Australian culture. The timing of the exhibit was impeccable, tapping into flourishing wider cultural interest in and creative engagement with Kelly. Kelly Culture ran at the same time as another, privately staged Kelly exhibition in Melbourne, The Legend of Ned Kelly; it preceded by a month the cinematic release of the Heath Ledger film, Ned Kelly; and it capitalised on the momentum created by the release in 2000 of Carey's Booker Prize winning novel, True History. ${ }^{50}$

In addition to rejuvenating and repurposing its built infrastructure, during this same period the library was also active in upgrading is informational infrastructure. For instance, in early 2003, the library launched an on-line reference service called AskNow! which enabled 'web surfers to pick the brains of skilled librarians and request information in real time, in an environment similar to an Internet chat 
room'. ${ }^{51}$ As the library's then manager of customer information services explains, developments such as this were seen as 'a way of building new and different relationships with our users and a way of enticing new groups to use library services' ${ }^{52}$

Importantly, the library's website and online reference services also yielded valuable audience or user measurement data. Just as people counters were used to track the number of physical visitors to the library, so, too, the number of hits was deployed to measure user engagement with its website. ${ }^{53}$ As Gerlitz and Helmond explain, 'Hit counters displayed a rough indication of the number of visitors to a page, derived from the number of computerised requests-hits-to retrieve the page, and became the standard measuring website traffic'. ${ }^{54}$ Indeed, alongside other measures, website visitation statistics were included among the library's 'key performance indicators' in its annual report for 2001-2002, with 1.2 million 'hits' recorded for that financial year. ${ }^{55}$ In a political climate where questions were rapidly being asked about the spiralling running costs associated with, and generally low patronage of, Victoria's redeveloped cultural institutions, the library's website was seen as a key resource within an 'audit culture' environment that was concerned with providing data to argue for and justify ongoing and maintained (if not increased) levels of government investment in resources and services. ${ }^{56} \mathrm{~A}$ library, it would seem, that delivered material in a way that was palatable and appealing to the wider public, and which moved with the times by embracing 'the digital', would stand a better chance of survival in such a fraught fiscal climate.

Thus, while Peter Carey's laptop was not necessarily central to a number of the above developments, its acquisition (which predates many of them) is of considerable symbolic importance. It functions as an important signifier of the library's desire to reconstruct its corporate image and reposition itself as both a vital contemporary cultural site and key player in Melbourne's institutional gallery scene and as a library 'for the 21st century'. As the library's annual report for 20022003 puts it, 'by engaging with emerging technologies and new media, readers, artists and innovators will be able to experience the Library of the future in the magnificent spaces of the past ${ }^{\prime} .{ }^{77}$ Carey's laptop constitutes an important item in this context. In the words of manuscripts librarian Kevin Molloy, 'the historical resonance between the laptop and [Kelly's Jerilderie] Letter was too significant to 
ignore, ${ }^{58}$ It is thus a vital collection piece which, through its contents, connects Victoria's rich cultural heritage to the present, and which, as a technological artefact, connects the present with one particular vision of the library as a cultural repository of and for a 'digital future'.

\section{—DIGITAL PRESERVATION AND INDUSTRIAL DISRUPTION}

In addition to its website redevelopment project, a key component of the library's larger modernisation agenda, and accompanying embrace of the digital, was a number of ongoing and new large-scale collection digitisation initiatives. For example, the library's 2001-2002 annual report states that, with philanthropic support, the library had 'completed an eight-year project to photograph and digitise the illustrations from the rare 19th-century Victorian illustrated newspapers held in its collection', with a total of 10,645 images made accessible, as well as continuing the task of digitally converting photographs of Australians during World War II from the Argus newspaper archive-a project that was completed the following year, with sixteen thousand photographs digitised. ${ }^{59}$ Further planned initiatives included the 'digital conversion of printed pamphlets, sheet music, audio recordings and manuscript finding aids'. ${ }^{60}$

That the Carey laptop acquisition featured prominently in this annual report, both in the CEO's summary and elsewhere (in text and image) is important. The inclusion of this technological artefact arguably works to position it, again, as a key symbol of the library's 'progressive' agenda, and its embrace of the 'digital' and, increasingly, of 'born digital content'.

Notably, included among the aforementioned list of digitisation achievements in the same annual report, the library also announced its 'Digital Strategic Plan 2001-04'. This initiative was developed to 'provide a framework for the Library's activities with electronic collections and services', which covered all facets of library process, from collection, to preservation and access. The Digital Strategic Plan was significant at the time in that it signalled a growing awareness within the library of the shifting technological landscape affecting large-scale research libraries, both in Australia and internationally. To cite two examples, it was in this same year2001-that Carnegie Mellon University Library in the United States announced its Million Book project, the ambitious stated goal of which was 'to capture all books in 
digital format'. ${ }^{61}$ Only three years later, Google Inc. announced its intentions to digitise the collections of five significant libraries, those of Stanford, Harvard, Oxford, the University of Michigan and the New York Public Library. ${ }^{62}$ This plan also signalled the need for the library to keep abreast of such changes.

Meanwhile, at the same time as recognising the importance of their own largescale digital conversion and preservation initiatives, there was also an evident awareness within the State Library of Victoria of the operational and resource implications of these endeavours. Thus, what accompanied the Digital Strategic Plan was, as reported in the 2002-2003 annual report, a 'comprehensive internal review of the Preservation and Storage Division ... [that was] aimed at aligning organisational design with business needs, priorities and resource capability’. ${ }^{63}$

The ultimate direction taken by these two internal library processesimplementing the strategic plan and the divisional review-was shaped by a variety of forces, including managerial agenda-setting and internal and external politicking. It is these complications that I wish to recount briefly here, as they are instructive for understanding the third sense in which Carey's laptop operated at the time of its acquisition as an important talisman for the library.

In 2001, the same year in which Carey's laptop was acquired, the architect of both these internal library initiatives, the then manager of the library's Preservation and Storage Division, wrote an article for the leading conservation industry journal, The Paper Conservator, titled 'Preserving Information in a Digital Age: What's the Difference ${ }^{{ }^{64}}$ It is a curious article insofar as it is cast as a series of despatches from the front line of digital preservation-a move repeated by the same author elsewhere - while at the same time attempting to 'stimulate thinking and discussion about the role of libraries in the management of digital resources ... and to challenge readers to tell us how they are managing digital resources now' ${ }^{65}$ Significantly, the article opens with a barrage of statistics that seek to illustrate the immense scale and growth of digital technologies and billowing global use of these resources. ${ }^{66}$ These developments, the reader is told, 'challenge the long-held view that preservation in libraries is primarily about caring for paper-based items and records' - a 'mindset' that is characterised rather provocatively in the article as 'electronic records: paper minds' ${ }^{67}$ Citing a US presidential advisory paper, the 'challenge' to libraries and their staff is presented as follows: 
Just to keep pace with the flood of new information, the library of the future will require the means to collect and make it available digitally; and because digital information is being produced so much more rapidly than other forms, libraries of the future will perforce increasingly be libraries of digital content. ${ }^{68}$

For those working within the library's Preservation and Storage Division at the time-of which I was one-the message rang clear. This article, in effect, set the agenda for the division-level restructure that was to follow. 'Paper minds' were going to have to readjust to, or make way for, 'electronic records'. The subsequent restructure included various waves of job cuts, and offers of voluntary departure packages.

Running in parallel with this restructure, which brought a further layer of complication to proceedings, was an ongoing and growing industrial dispute between the Community and Public Sector Union (the CPSU) and their members, and library management and the state government. ${ }^{69}$ At the heart of this dispute was the CPSU's demand that the library and government double its offer of a three per cent wage rise, and implement a review of internal career structures. ${ }^{70}$ In order to hasten stalled negotiations, on 10 February 2003, staff implemented a series of work bans affecting book deliveries, management of the online book delivery system, statistical collection and the staffing of service points within the library. ${ }^{71}$ After a series of stoppages and protests throughout that month, on 28 February 2003 library staff, donning 'Ned Kelly-style helmets, made of black cardboard' and carrying protest banners, walked off the job and confronted media attending the launch of the Kelly Culture exhibition. ${ }^{72}$ During this protest, the library's CPSU delegate described librarians' wages as a 'crime' and restated their demand for a six per cent pay rise. ${ }^{73}$

With press attention focused firmly on the ongoing and very public union-led wage dispute, what went largely unnoticed, and was not reported at the time, was the implications of the Preservation and Storage Division restructure for the State Collection. A key plank to the restructure agenda was the reduction of collection conservation to a skeleton operation (if not entirely dismantling it) in favour of a substantial expansion of the library's reproduction and collection digitisation operations. While lacking the visibility of front-of-counter librarians, the Collection 
Conservation department performs a crucial, if admittedly time-intensive and costly, function. It involves a significant number of highly trained staff and specialist equipment and resources to redress and slow deterioration brought about by age, wear-and-tear and other factors, to the library's extensive holdings of books, written manuscript materials, photographs, paintings and other objects and items. ${ }^{74}$ One of its core functions is also the maintenance of the State Collection, the upkeep of which is enshrined in Section 18 of the Victorian Libraries Act $1988 .{ }^{75}$ One of the real concerns of conservation staff at the time was that, in addition to the threat of losing their own jobs, the restructure placed the State Collection at significant risk.

This proposal, as it turns out, did not eventuate. That it did not was the result of a number of factors, not least of which was a change in leadership. In mid-2002, before the completion of the Preservation and Storage Division review, the library's CEO, Fran Awcock, announced her retirement. ${ }^{76}$ Her replacement, Anne-Marie Schwirtlich, took over in early 2003 and, coming from a background working in archives, brought with her a different set of perspectives and strategic priorities. ${ }^{77}$ Arguably, the other key reason the proposed restructure never proceeded as planned was because it was premised on a 'solutionist' view of technology that saw digital conversion and preservation initiatives as the way forward. ${ }^{78}$ This view neglected to fully consider other significant contextual factors, such as staffing requirements (including the fact that the revamped library required a healthy level of Collection Conservation staff to service its newly minted gallery spaces) and the technical challenges and significant costs associated with digital preservation and associated projects. The 'digital idyll' of such preservation initiatives, Patricia Cohen notes in a 2010 piece for the New York Times, 'has its own set of problems':

As research libraries and archives are discovering, 'born-digital' materials-those initially created in electronic form-are much more complicated and costly to preserve than anticipated. Electronically produced drafts, correspondence and editorial comments, sweated over by contemporary poets, novelists and nonfiction writers, are ultimately just a series of digits-0's and 1's-written on floppy disks, CDs and hard drives, all of which degrade much faster than old-fashioned acid-free paper. ${ }^{79}$

The specific symbolic emblem for this plan to reconfigure library operations in support of digital preservation, let's not forget, was Carey's laptop computer, a 
technological object which, while held up as representing the epitome of 'progress', entered the library as 'old media', a museum piece itself in need of preservation.

\section{- CONCLUSION}

In this article I have explored the circumstances surrounding the 2001 purchase of Peter Carey's Apple Mac Classic laptop computer by the State Library of Victoria. The argument that I have developed here is that this laptop represented much more than just a means of gaining ready access to Carey's drafts of True History of the Kelly Gang and editorial correspondence. Rather, the laptop is an important media archaeological artefact, one that is instructive for understanding the material turn in information and media studies and the 'immaterial' turn in preservation/archival studies. ${ }^{80}$ Sedimented within this object are three distinctive but interconnected sets of code-labour relations.

First, within the antiquated code of the word processing software-'the computer was so old that the files did not even have extensions (such as .doc) ${ }^{81}$ lay the fruits of Carey's intellectual labours and the promise of privileged access to his creative drive, and of his channelling of Ned Kelly's voice via his own authorial voice.

Second, upon its purchase, the laptop was 'recodified' within official library reports and press coverage, taking on crucial symbolic significance as part of a reconstructed corporate image that endeavoured to reposition the State Library of Victoria as a vital contemporary cultural site and key player in Melbourne's institutional gallery scene. The laptop was one of the first items to be placed on display when the library opened its new gallery spaces. Within this exhibition context, the laptop was to provide insight into the shifting technological form of the book itself, as well as the role of digital technology in all stages of labour involved in developing a work of literature, from gathering research notes, through to typed drafts and editorial correspondence, and its subsequent publication.

Third, and finally, Carey's laptop spoke to certain desires within library management at the time of its acquisition, which responded to similar moves at major libraries elsewhere around the world to embrace collection digitisation and digital preservation as both an inevitability, as desirable for the labour-saving they 
were said to promise and as the most expedient way forward for large-scale research and legal deposit libraries.

The underlying argument of this article can be summarised as follows: just as 'all media were once new', so too it is the case that 'old' or 'residual' media are frequently 'renewed', often in surprising ways. ${ }^{82}$ As Raymond Williams writes, 'the residual, by definition, has been effectively formed in the past, but it is still active in the cultural process, not only and often not at all as an element of the past, but as an effective element of the present' and, just as often, of the future. ${ }^{83}$ Peter Carey's laptop entered the State Library of Victoria at a quite specific moment in time: when the large cultural institution was in the midst of significant change and transformation and subject to internal as well as external upheaval. It was within this setting, with its complicated confluence of factors, that this particular artefact (an established technology of writing in a long line of established technologies of writing, including paper itself) became an 'active' agent in the cultural processes, a highly charged symbolic object-a talismanic object-that spoke to (and was mobilised around) certain myths and desires concerning the transformative potential of 'the digital'. What I have presented here, of course, is one very specific tale about one very specific artefact in its own very specific cultural context. Nevertheless, what this episode highlights, I would suggest, is the need for media and communication and cultural studies scholarship to be attuned to the often unexpected ways that even the most humble of 'residual' technological objects can take on 'a semiotic richness ripe for appropriation'. ${ }^{84}$

Rowan Wilken is a senior lecturer in Media and Communications at Swinburne University of Technology, Melbourne, Australia, and holds an Australian Research Council funded research fellowship (ARC DECRA) in the Swinburne Institute for Social Research. His present research interests include mobile and locative media, digital technologies and culture, theories and practices of everyday life, domestic technology consumption, and old and new media. He has published widely on mobile and location-based media. He is the co-editor (with Gerard Goggin) of 
Locative Media (forthcoming) and Mobile Technology and Place (2012), and is the author of Teletechnologies, Place, and Community (2011).

-Notes
${ }^{1}$ Jacques Derrida, Paper Machine, trans. Rachel Bowlby, Stanford University Press, Stanford, 2005, $\mathrm{p}$.

29.

${ }^{2}$ Roland Barthes, Writer Sollers, trans. Philip Thody, University of Minnesota Press, Minneapolis, 1987, p. 78.

${ }^{3}$ While it would be nice to think that the lack of an 'o' key was some kind of elaborate, pre-set Oulipian constraint, this is in fact not the case. I checked, and the letter o figures prominently in Carey's novel.

${ }^{4}$ Jock Murphy, 'A Major Literary Acquisition: Peter Carey Manuscripts-and Laptop Computer', State Library of Victoria News, no. 19, February-May, 2002, p. 3.

${ }^{5}$ Kevin Molloy, manuscripts librarian, State Library of Victoria, email, 16 December 2010.

${ }^{6}$ Derrida, p. 21.

${ }^{7}$ Nietzsche, quoted in Friedrich A. Kittler, Gramophone, Film, Typewriter, trans. Geoffrey WinthropYoung and Michael Wutz, Stanford University Press, Stanford, CA, 1999, p. 200; Walter J. Ong, Orality and Literacy: The Technologizing of the Word, Routledge, London, 1995, p. 82. Following a similar line of argument, Nathan Ensmenger writes: 'The tools we use to think with affect the character of our thoughts; to write something down is to transform it.' Nathan Ensmenger, 'The Digital Construction of Technology: Rethinking the History of Computers in Society', Technology and Culture, vol. 53, pp. 753754.

${ }^{8}$ Derrida, p. 25. In an amusing aside, Derrida comments on the 'software agent' interrupting his writing and giving him, 'like an order coming from I know not whom', a 'slightly threatening warning' to finish his paragraph (p. 22).

${ }^{9}$ Derrida, p. 24. See also, Kathleen Fitzpatrick, 'The Digital Future of Authorship: Rethinking Originality', Culture Machine, vol. 12, 2011, pp. 1-26,

<http://www.culturemachine.net/index.php/cm/article/view/433/466>.

${ }^{10}$ Mark Poster, The Mode of Information: Poststructuralism and Social Context, Polity Press, Cambridge, 1990, p. 111. In contrast to this, N. Katherine Hayles presents a very different perspective on the materiality of writing: 'It is not merely an inert collection of physical properties but a dynamic quality that emerges from the interplay between the text as a physical artefact, its conceptual content, and the interpretive activities of readers and writers. Materiality thus cannot be specified in advance; rather, it occupies a borderland-or better, performs as connective tissue-joining the physical and mental, the artefact and the user'. N. Katherine Hayles, 'Print is Flat, Code is Deep: The Importance of MediaSpecific Analysis', Poetics Today, vol. 25, no. 1, 2004, p. 72. 
${ }^{11}$ Kittler, p. 206; Poster, p. 111.

${ }^{12}$ Derrida, p. 23.

${ }^{13}$ Poster, p. 111.

${ }^{14}$ Jane Sullivan, 'True History of a Writer', Age ('Extra'), 6 October 2001, p. 3.

${ }^{15}$ Anthony Quinn, 'Robin Hood of the Outback', New York Times, 7 January 2001,

<http://www.nytimes.com/books/01/01/07/reveiws/010107.07quinnt.html>; Steve Meacham,

'Writer's Craft is Now a Ghost in the Machine', Sydney Morning Herald, 7 January 2012, <http://

http://www.smh.com.au/entertainment/books/writers-craft-is-now-a-ghost-in-the-machine-

20120106-1po2l.html>.

${ }^{16}$ Peter Carey quoted in Allison Holland and Clare Williamson, 'Kelly Culture', Kelly Culture:

Reconstructing Ned Kelly, State Library of Victoria, Melbourne, p. 14.

${ }^{17}$ Paul Gray, 'Peter Carey brings Australia's Legendary Ned Kelly Vibrantly to Life', Time, 22 January 2001, p. 82.

${ }^{18}$ Peter Porter, 'Made Noble in the Fire', Times Literary Supplement, 5 January 2001, pp. 19-20; Malcolm Jones, 'An Outlaw Down Under', Newsweek, 29 January 2001, p. 64.

${ }^{19}$ Nathanael O'Reilly, 'The Voice of the Teller: A Conversation with Peter Carey', Antipodes, December 2002, 164-7; Shaunagh O'Connor, 'Bandit King', Herald-Sun, 18 February 2003, p. 29.

${ }^{20}$ Poster, p. 113.

${ }^{21}$ Ibid.

${ }^{22}$ Ibid.

${ }^{23}$ Ibid., p. 114.

${ }^{24}$ Richard Winston and Clara Winston, translators' note in Thomas Mann, The Selected Letters of Thomas Mann 1889-1955, selected and trans. Richard Winston and Clara Winston, Penguin,

Harmondsworth, 1975, p. 256, note 2. To give one example, Thomas Mann records in a letter to the USbased Austrian writer Viktor Polzer: 'I work by myself and write by hand, nowadays [the letter is dated 1940] using what is here [in the United States] called a desk fountain pen instead of the steel nib I formerly used'. Mann, The Selected Letters of Thomas Mann 1889-1955, p. 256. In a newspaper article profile of US writer Paul Auster, the journalist observes, 'on the wall are three paintings of his Olympia typewriter by the artist Sam Messer, with whom he collaborated on The Story of My Typewriter (2002). Auster writes in longhand but types up his paragraphs immediately before he's unable to decipher his crabbed handwriting.' Ben Naparstek, 'Taking a Chance with Paul Auster', Age ('Books'), 23 February 2008, p. 27.

${ }^{25}$ Ray Cassin, 'An Australian Classic Restored to Intended Glory', Age, 13 October 2007, p. 11.

${ }^{26}$ Sullivan, p. 3. Kevin Molloy, manuscripts librarian, State Library of Victoria, email, 16 December 2010.

${ }^{27}$ Derrida, p. 29.

${ }^{28}$ Ibid. 
${ }^{29}$ Sullivan, p. 3. Indeed, the press has played an important role in reinforcing this perspective on authenticity, with at least two articles on Carey featuring prominent pictures of him writing at a laptop computer. See, for example, Sharon Verghis, 'The Many Lives of Peter Carey', Age Good Weekend, 19 January 2008, pp. 15, 18; Jason Steger, 'Writer in Residence: Peter Carey', Age, 23 August 2008, <http://www.theage.com.au/articles/2003/08/21/1061434988889.html>.

${ }^{30}$ Meacham, emphasis added.

${ }^{31}$ Murphy, p. 3.

${ }^{32}$ Kevin Molloy, manuscripts librarian, State Library of Victoria, email, 16 December 2010.

${ }^{33}$ Hillel Schwartz, The Culture of the Copy: Striking Likenesses, Unreasonable Facsimiles, Zone Books, New York, 1996, p. 212.

${ }^{34}$ Schwartz, pp. 257, emphasis added.

${ }^{35}$ Sullivan, p. 3.

${ }^{36}$ Steven Lubar, 'Exhibit Review: The Computer Museum, Boston, Massachusetts', Technology and Culture, vol. 27, no. 1, 1986, p. 96.

${ }^{37}$ The Mirror of the World, State Library of Victoria, <http://www.slv.vic.gov.au/event/mirror-world>.

${ }^{38}$ This particular laptop has been on display here since the exhibition opened and still is, 'apart from a 12 month period (November 2008 - November 2009) when it came off display for use in The Independent Type exhibition in the Keith Murdoch Gallery (April - October 2009)', during which time it was replaced in The Mirror of the World exhibition by his white G4Mac iBook. Clare Williamson, senior exhibitions curator, State Library of Victoria, email, 27 March 2013.

${ }^{39}$ Murphy, p. 3.

${ }^{40}$ George J. Leonard, Into the Light of Things: The Art of the Commonplace from Wordsworth to John Cage, University of Chicago Press, Chicago, 1994, pp. 6-7.

${ }^{41}$ Arthur C. Danto, 'The Transfiguration of the Commonplace', Journal of Aesthetics and Art Criticism, vol. 33, no. 2, 1974, pp. 139-48.

${ }^{42}$ As described, for example, in Lubar, pp. 96-105.

${ }^{43}$ Sharon Macdonald, 'Exhibitions of Power and Powers of Exhibition: An Introduction to the Politics of Display', in Sharon Macdonald (ed.), The Politics of Display: Museums, Science, Culture, Routledge,

London, 1998, p. 2.

${ }^{44}$ Macdonald, p. 1.

${ }^{45}$ Rebecca Lancashire, 'Review: Hang the Expense', Age, 17 January 2004, <http://www.theage.com.au/articles/2004/01/14/1073877895371.html>.

${ }^{46}$ Ibid.

${ }^{47}$ Ibid.

${ }^{48}$ Tanya Giles, 'Library Reading Room Reopens', Herald Sun, 9 July 2003, p. 12; Meaghan Shaw, 'Refurbished Library Tells Victoria's Tales', Age, 25 June 2002, 
<http://www.theage.com.au/articles/2002/06/24/1023864554361.html>; Simon Plant, 'Dome Sweet Dome', Herald Sun, 7 June,2003.

${ }^{49}$ Shaw.

${ }^{50}$ See, for example: 'New Look at Kelly Culture', Herald Sun, 20 February 2003, p. 13; Ross Brundrett, 'Ned Reckoning', Herald Sun, 22 February 2003; Lillian Frank, 'Right or Wrong, Ned's Exhibition a Winner', Herald Sun, 1 March 2003, p. 107; Shaunagh O'Connor, 'Bandit King', Herald Sun, 18 February 2003, p. 29; Christopher Bantick, 'Ned Kelly-Terrorist', Herald Sun, 25 February 2003, p. 19; Imre Salusinszky, 'Blood-lusting Urban Bushrangers, Your Nation Needs You', Australian, 3 March 2003, p.

21.

${ }^{51}$ Greg Thom, 'Online to Your Library', Herald Sun, 22 January 2003.

${ }^{52}$ Ibid.

${ }^{53}$ See Dave D'Alessio, 'Use of the World Wide Web in the 1996 US Election', Electoral Studies, vol. 16, no. 4, 1997, p. 494.

${ }^{54}$ Carolin Gerlitz and Anne Helmond, 'The Like Economy: Social Buttons and the Data-Intensive Web', New Media \& Society, online first, 4 February 2013, p. 3.

${ }^{55}$ Library Board of Victoria, Annual Report 2001-02, State Library of Victoria, Melbourne, 2002, p. 11.

${ }^{56}$ Editorial, 'Major Projects, With Major Running Costs', Age, 13 March 2003, p. 16; Robin Usher, 'Museums Cut the Cost of Culture', Age, 15 May 2003, p. 6.

${ }^{57}$ Library Board of Victoria, Annual Report 2002-03, State Library of Victoria, Melbourne, 2003, p. 4.

${ }^{58}$ Kevin Molloy quoted in Rachel Buchanan, “'Sweeping Up the Ashes”: The Politics of Collecting Personal Papers', Australian Book Review, December 2011 - January 2012, p. 52.

${ }^{59}$ Library Board of Victoria, Annual Report 2002-03, pp. 19, 18, 25.

${ }^{60}$ Library Board of Victoria, Annual Report 2001-02, p. 18.

${ }^{61}$ Karen Doyle, 'Mass Digitization of Books', The Journal of Academic Librarianship, vol. 32, no. 6, 2006, p. 642.

${ }^{62}$ Carolyn Said, 'Revolutionary Chapter: Google’s Ambitious Book-scanning Plan Seen as Key Shift in Paper-based Culture', SFGate.com, 20 December 2004, <http://www.sfgate.com/business/article/Revolutionary-chapter-Google-s-ambitious-2662491.php>. ${ }^{63}$ Library Board of Victoria, Annual Report 2002-03, State Library of Victoria, Melbourne, 2003, p. 52.

${ }^{64}$ Alan Howell, 'Preserving Information in a Digital Age: What's the Difference?', The Paper Conservator, vol. 25, no. 1, 2001, pp. 133-49.

${ }^{65}$ Alan Howell, 'Digital Imaging Technology for Preservation and Access: A Cornell University Library Workshop', LASIE: Information Bulletin of the Library Automated Systems Information Exchange, March 1996, pp. 26-41; Howell, 'Preserving Information in a Digital Age', p. 134.

${ }^{66}$ Howell, 'Preserving Information in a Digital Age', p. 133.

${ }^{67}$ Ibid., p. 134.

${ }^{68}$ Ibid. 
${ }^{69}$ This was part of a larger series of industrial disputes pitting the CPSU against the Bracks government. See Susie 0’Brien, 'More Pay, Fewer Hours', Herald Sun, 20 January 2003, p. 12.

70 'Library Row Worsens', Herald Sun, 10 February 2003, p. 13.

71 'Library Row Worsens'.

72 'Library Dispute Flares', Herald Sun, 20 March 2003, p. 22; 'Staff Walk', Herald Sun, 27 March 2003, p. 26. While it received considerable news coverage, not all of it took the dispute particularly seriously. I recall, for instance, one journalist at the time writing of mentally picturing a public rally where participants and bystanders are told to be quiet.

73 'Such is Life at Library', Herald Sun, 28 February 2003, p. 11.

${ }^{74}$ At the time, the major university conservation course in Australia had a tertiary degree as a baseline entry prerequisite.

${ }^{75}$ Libraries Act 1988, <http://www.austlii.edu.au/au/legis/vic/consol_act/la1988105/>. For a definition of the State Collection, see Part 1, Section 4 of the Act.

${ }^{76}$ Farah Farouque, 'The Future is Fran's', Age, 30 June 2002, <http://www.theage.com.au/articles/2002/06/29/1023864668436.html>.

77 'One for the Books', Herald Sun, 17 January 2003, p. 26.

${ }^{78}$ Evgeny Morozov, To Save Everything, Click Here: The Folly of Technological Solutionism, Public Affairs, New York, 2013.

${ }^{79}$ Patricia Cohen, 'Fending Off Digital Decay, Bit by Bit', The New York Times, 16 March 2010, $<$ http://www.nytimes.com/2010/03/16/books/16archive.html?pagewanted=all\&_r=0>.

${ }^{80}$ Jussi Parikka, What is Media Archaeology?, Polity, Cambridge, 2012.

${ }^{81}$ Buchanan, p. 52.

${ }^{82}$ Lisa Gitelman, Always Already New: Media, History, and the Data of Culture, MIT press, Cambridge, MA, 2008, p. 1.

${ }^{83}$ Raymond Williams, quoted in Charles R. Acland, 'Introduction: Residual Media' in Residual Media, ed. Charles R. Acland, University of Minnesota Press, Minneapolis, 2007, p. xxi.

${ }^{84}$ Acland, 'Introduction', p. xvii. 